\title{
The impact of a specific training programme on the selected parameters of swimming turns
}

\author{
(D) Zuzana Pupišová ${ }^{1}$, (iD Martin Pupišs ${ }^{1}$, (D) Jozef Sýkora ${ }^{1}$, \\ (1) Dávid Brunn ${ }^{1}, \quad$ (1) Jana Giničová1, (i) Ratko Pavlović \\ ${ }^{1}$ Department of Physical Education and Sport, Faculty of Arts, MatejBel University, Slovak Republic \\ ${ }^{2}$ Faculty of Physical Education and Sport, University of East Sarajevo, Bosnia and Herzegovina.
}

\begin{abstract}
The presented study focuses on the impact analysis of a specific training programme primarily focusing on plyometric exercises for the lower limb explosive power, and the selected parameters of swimming turns. The tested set consisted of performance swimmers $(n=20$, men $n=12$ and women $\mathrm{n}=8$ ) in the average age of 17.3 years, average height of $174.2 \mathrm{~cm}$, and average weight of $65.8 \mathrm{~kg}$. The tested set was divided into two smaller sets. The experimental set $(\mathrm{n}=10)$ used the training process as an extra experimental factor and the supervision set $(\mathrm{n}=10)$ carried out only the main contents of the training process. The specific training schedule was applied during the period of 8 weeks, three times a week for 20 minutes. The effectiveness of the experimental factor was tested through a selected set of tests, focusing primarily on the lower limb explosive power. Three of the tests were conducted on the dryland using the Myotest machine: T1 - Squat jump (SJ), T2 Countermovement Jump (CMJ) and T3 - Plyometric jump (PJ). The tests conducted in the swimming pool were: T4 - max. length of floating up after the push off from the turning wall, and T5 - the length of push off after $25 \mathrm{~m}$ of breaststrokes in the maximum speed with a push off from the wall of maximum floating up. The results pointed out a proportionally higher increase in the experimental set, in which the average percentile improvement of the jump height amounted to $17.7 \%$ in $\mathrm{T} 1$ (the changes in the supervision set were $0.7 \%$ ); in $\mathrm{T} 2$ the jump height was increased by $22 \%$ (the changes in the supervision set were $0.6 \%$ ); in $\mathrm{T} 3$ the time of contact increased by $18.5 \%$ (the supervision set showed a decrease by $1.2 \%$ ), $\mathrm{T} 4$ by $14.9 \%$ (the changes in the
\end{abstract}

supervision set were $4.1 \%$ ) and in $\mathrm{T} 5$ by $22.7 \%$ (the changes in the supervision set were $11.0 \%$ ). Kendall correlation coefficient (r), pointed out the average value of the correlation coefficient between the experimental factor and the individual tests as follows: $\mathrm{T} 1: \mathrm{r}=0.39$, $\mathrm{p}<0.05 ; \mathrm{T} 2: \mathrm{r}=0.41, \mathrm{p}<0.05 ; \mathrm{T} 3: \mathrm{r}=0.43, \mathrm{p}<0.05, \mathrm{~T} 4: \mathrm{r}=$ $0.38, \mathrm{p}<0.05$ a T5: $\mathrm{r}=0.41, \mathrm{p}<0.05$. In conclusion, practice, improvement, and affectivity of the swimming turn can affect the swimmers' performance in races and improve it.

Keywords. Lower limb explosive power, performance swimming, plyometric exercises, swimming performance.

\section{Introduction}

The term plyometric is a combination of two Greek words, plio and metric, which are translated as: to measure or to achieve more. Verchošanskij, an expert in strength, is considered to be the founder of modern plyometric. The plyometric method used to be called the shock method as it forces the muscles to produce the highest tension. Zatsiorsy \& Kraemer (2006) define plyometric movement as a fast-explosive movement with a countermovement. The goal is an extension of the muscle followed by a concentric contraction (the extend - contract cycle). The efficiency of the plyometric movement lies in the increase of mechanical performance by using the elasticity of the muscle and tendon stretching reflect (Baechle \& 
Earle, 2008). However, the selected training should fulfil all the possible demands of the event. In general, what is good for one sports person, does not have to be beneficial for another (Psotta, 2006). The plyometric method can be considered one of the most frequently used training methods for increasing the explosive power. Multiple authors have focused on plyometric and its impact, e.g. Brooks et al. (1996); Cacek et al., (2007); Chu (1998); Kutz (2008); McGlashana (2004); Psotta (2006); Tihanyih (2002); Vanderka \& Kampmiller (2008), and others.

Plyometric consists of fast slow-down and the subsequent fastening in the opposite direction. The exercise allows the muscles to exert maximum power in minimum time. The power positively affects the ability to use the elastic energy of the adduct reflex and to effectively stimulate neural factors which condition the speed of exerting power (Radcliffe \& Farentinos, 1999). The body uses its $\mathrm{CP}$ system to create the needed energy (ATP) for muscle contraction, while carrying out the plyometric exercises in short time with high intensity. The ATP stores must be barely used up before re-synthetisation happens. Approximately $70 \%$ of ATP is restored after approximately $30 \mathrm{~s}$ and $100 \%$ after $3 \mathrm{~min}$. This is however individual. If every push off requires maximum effort, it is important to include the appropriate recovery between the individual acts. Plyometric exercises for developing explosive power should consist of highly intensive series up to four seconds (Cacek et al., 2007). Slamka (2000) says that plyometric training needs to primarily focus on the fastness of muscle extension, rather than the extent of it. Plyometric training needs to primarily focus on the fastness of muscle extension, rather than the extent of it. The length of the training unit should not exceed 20 to 30 minutes, which this research tried to abide by. Extra 10 to 15 minutes should be selected for the warm-up and cool down at the end of the training unit (Chu, 1998). The plyometric method positively affects the ability to use elastic power, as mentioned above. Fast retarding movements and the extension of elastic structures of muscles and tendons take place during the progressive eccentric contractions. Higher production of elastic energy happens as a result. If the shortening of a muscle happens immediately after, the elastic energy starts to loosen up and the overall production of powers is increased (Psotta, 2006).

The explosive power through plyometric method was selected for increasing the performance and affectivity of the breaststroke turn. The explosive power is known to manifest itself in swimming primarily during the start kick, swimming kicks, and during push off while performing a swimming turn. The positive influence of the changes in the lower limb explosive power on the efficiency of the start kick was already confirmed by a research conducted with top-level swimmers of the Slovak Republic (Pupišová, 2013). The intention of the submitted study is to find out the effectiveness of the changed in lower limb explosive power on the effectiveness of the swimming turn.

The research and the submitted study have been conducted and processed under the support of the grant VEGA 1/0788/16. The structure of sport performance and optimization of load in swimming and triathlon.

The objective of the study is to analyse the impact of a specific training programme which focuses on plyometric exercises for the lower limb explosive power and the selected parameters of swimming turns.

\section{Methods}

\section{Participants}

The tested set consisted of 20 performance swimmers, $n=12$ men and $n=8$ women, from the Slovak Republic. During the research, the set was in the average decimal age of $17.3 \pm 1.46$ years, height $=174.2 \pm .7 .5 \mathrm{~cm}$ and weight $=65.8 \pm 9.2 \mathrm{~kg}$. Average training age of the tested set was 9.3 years.

\section{Measurement organisation}

The testing was conducted in one day. The testing was conducted in the gym and pool areas. The pool is 25 meters long, 12.5 meters wide, 2.10 meters deep on the starting side and 1.20 deep on the turning side. The heat of the water was measured 
to be $28^{\circ} \mathrm{C}$ at the testing time. The research was conducted in the morning hours, between 8:00 and 10:00 A.M. The time interval is the first performance peak of the day, according to Jančoková (2000). It is also important to mention the fact that the men and women of the observed set did not go through any specific preparation focused on the selected matter before undergoing the research itself.

\section{Measurement}

The tested set underwent the testing in one day. First, they underwent the testing on dryland between 8:00 - 8:45 A.M. and in water between 9:00 - 10:00 A.M. The entry measurements were conducted on the 7 April 2017 and the outcome measurements on 5 June 2017. Before testing on the dryland, the set warmed up (15 minutes) and before testing in water they warmed up in the water (500 meters). The experimental factor was applied during the period of eight weeks, three times a week for 20 minutes. The supervision set, and the experimental set underwent the same exercises in all training units on dryland and in water. However, the experimental set underwent an experimental stimulus before the training in water. The contents of the experimental factor are shown in Tables $1-4$. The tested set underwent the testing on dryland, which consisted of three tests ( $\mathrm{T}_{1}$-Squat jump (SJ), $\mathrm{T}_{2}$ Countermovement Jump (CMJ) and $\mathrm{T}_{3}$ - Plyometric jump (PJ). Each test contained five sets. Two parameters were observed in the pool: $T_{4}-$ max. length of floating up after the push off from the turning wall $(\mathrm{m})$ and $\mathrm{T}_{5}$ - the length of the push off after $25 \mathrm{~m}$ of breaststrokes in maximum speed with a push off from the wall of maximum floating up, while the distance was measured from the pool wall to the fingertips in floating position.

\section{Table 1}

The experimental factor during Weeks 1 and 2 (Pupišová, 2013).

\begin{tabular}{lccclccc}
\hline \multicolumn{1}{c}{ Monday/Friday } & \multicolumn{1}{c}{ Wednesday } \\
\hline \multicolumn{1}{c}{ Exercise } & PO & PS & IO & Exercise & PO & PS & IO \\
\hline 1.Skipping rope (feet together) & 70 & 2 & 60 & 1.Skipping rope (alternate feet) & 70 & 2 & 60 \\
2.Jump - leap (30 cm box) & 3 & 3 & 90 & 2.Repeated push off from half-squat & 6 & 3 & 120 \\
3.Jump with swinging arms (T) & 5 & 3 & 120 & 3.Leap onto a box 30cm into a calf raise & 3 & 3 & 120 \\
4.Jump over an obstacle 30 cm & 4 & 2 & 120 & 4. Multiplied push off & 4 & 2 & 180 \\
\hline
\end{tabular}

\section{Table 2}

The experimental factor during weeks 3 and 4 (Pupišová, 2013).

\begin{tabular}{lccccccc}
\hline \multicolumn{1}{c}{ Monday/Friday } & & & & \multicolumn{2}{c}{ Wednesday } \\
\hline \multicolumn{1}{c}{ Exercise } & PO & PS & IO & Exercise & PO & PS & IO \\
\hline 1. Skipping rope (alternate feet) & 100 & 2 & 60 & 1. Skipping rope (feet together) & 100 & 2 & 90 \\
2. Jump from a squat, feet together (arms akimbo) & 3 & 3 & 90 & 2. Multiple jumps over obstacles & 4 & 3 & 180 \\
3. Jump off a box 30cm-jump over obstacle $20 \mathrm{~cm}$ & 5 & 3 & 120 & 3. Lunges & 5 & 4 & 90 \\
4. Jump over an obstacle $30 \mathrm{~cm}$ & 4 & 2 & 120 & 4. Jump with swinging arms (G) & 3 & 3 & 120 \\
\hline
\end{tabular}

Table 3

The experimental factor during weeks 5 and 6 (Pupišová, 2013).

\begin{tabular}{lccclccc}
\hline \multicolumn{1}{c}{ Monday/Friday } & \multicolumn{1}{c}{ Wednesday } \\
\hline \multicolumn{1}{c}{ Exercise } & PO & PS & IO & \multicolumn{1}{c}{ Exercise } & PO & PS & IO \\
\hline 1.Skipping rope (feet together) & 80 & 3 & 90 & 1.Skipping rope (alternate feet) & 80 & 3 & 90 \\
2. Jump - leap 30cm box & 4 & 5 & 120 & 2.Jump - leap 30cm box & 4 & 5 & 120 \\
3.Triple jump & 2 & 2 & 240 & 3.Multiple jumps over obstacles 30cm & 4 & 2 & 180 \\
4.Jump - leap 30cm box & 3 & 4 & 120 & 4. Jumps with swinging arms (T) & 4 & 3 & 150 \\
\hline
\end{tabular}


Table 4

The experimental factor during weeks 7 and 8 (Pupišová, 2013).

\begin{tabular}{lccccccc}
\hline \multicolumn{1}{c}{ Monday/Friday } & \multicolumn{4}{c}{ Wednesday } \\
\hline \multicolumn{1}{c}{ Exercise } & PO & PS & IO & Exercise & PO PS & IO \\
\hline 1.Skipping rope (alternate feet) & 10 & 3 & 120 & 1.Skipping rope (feet together) & 100 & 3 & 120 \\
2.Jump from box 70cm & 5 & 2 & 150 & 2.Jumping over obstacles 30cm & 4 & 2 & 150 \\
3.Leaping onto a box 30cm into a calf raise & 4 & 3 & 180 & 3. Jump - leap 30cm box & 3 & 3 & 120 \\
4.Multiple jumps through obstacles & 3 & 3 & 180 & 4.Lunges & 5 & 3 & 120 \\
& & & & 5.Jumping with swinging arms (G) & 4 & 3 & 150 \\
\hline
\end{tabular}

\section{Data analyses}

We chose the following descriptive statistics characteristics - for measurements of central tendency we used the arithmetic mean ( $\mathrm{x}$ ) and for measures of variability the standard deviation (SD). We used also minimal (min) and maximal (max) value of individual's parameters. The Kendall correlation coefficient (r) was used for the statistical finding of the significance of linear variation between the observed parameters. The coefficient was interpreted as follows: under $0.1-$ trivial correlation, $0.1-0.3$ - low correlation, $0.3-0.5$ -medium correlation, over 0.5 - high correlation (Cohen, 1988). The statistical analysis was conducted through the IBM® SPSS® Statistics V19 (Statistical Package for the Social Sciences) software.

\section{Results and Discussion}

The presented study focused on the impact analysis of a specific training programme which mostly involves plyometric exercises for the lower limb explosive power and the selected parameters of swimming turns. The results can be found in Tables 5-9.

Table 5 shows the results of the $\mathrm{T}_{1}$ test in the experimental and supervision sets. The comparison of the average values of the sets shows, that the experimental set has reached a more significant improvement in all parameters, while the supervision set has even showed worsening in the parameters: Power (by 0.1W), Velocity (by $7.2 \mathrm{~cm} / \mathrm{s}$ ) a Pmax (by 0.9). Significant improvement was recorded in the experimental set. Therefore, it can be stated, that the application of the specific programme focused on the lower limb explosive power was effective (in the height by $5.9 \mathrm{~cm}$ parameter).

Table 5

Results of the $\mathrm{T}_{1}$ test in experimental and supervision sets.

\begin{tabular}{|c|c|c|c|c|c|c|c|c|c|c|}
\hline \multirow{2}{*}{$\mathrm{ES} / \mathrm{KS}$} & $\mathrm{t}_{1}$ & $\mathrm{t}_{2}$ & $\mathrm{t}_{1}$ & $\mathrm{t}_{2}$ & $\mathrm{t}_{1}$ & $\mathrm{t}_{2}$ & $\mathrm{t}_{1}$ & $\mathrm{t}_{2}$ & $\mathrm{t}_{1}$ & $t_{2}$ \\
\hline & \multicolumn{2}{|c|}{ Height $(\mathrm{cm})$} & \multicolumn{2}{|c|}{ Power $(W)$} & \multicolumn{2}{|c|}{ Velocity $\mathrm{cm} / \mathrm{s}$ ) } & \multicolumn{2}{|c|}{ Force $(\mathrm{N} / \mathrm{kg})$} & \multicolumn{2}{|c|}{ P.max } \\
\hline SD & 2.9 & 3.9 & 4.5 & 4.8 & 14.9 & 16.0 & 1.6 & 1.6 & 4.3 & 6.3 \\
\hline Min & 28.6 & 32.6 & 31.7 & 36.2 & 213.0 & 193.0 & 17.6 & 20.7 & 33.4 & 36.1 \\
\hline Max & 36.4 & 44.1 & 44.7 & 50.7 & 256.0 & 231.0 & 22.7 & 25.4 & 45.4 & 51.2 \\
\hline Mean & 33.4 & 39.3 & 40.1 & 44.6 & 237.4 & 214.6 & 20.3 & 23.3 & 41.4 & 44.5 \\
\hline SD & 3.3 & 3.0 & 6.7 & 6.0 & 19.5 & 17.5 & 3.1 & 3.0 & 6.6 & 7.1 \\
\hline Min & 24.1 & 24.8 & 31.7 & 31.9 & 209.0 & 218.0 & 17.2 & 18.5 & 34.8 & 32.9 \\
\hline Max & 34.0 & 34.1 & 50.6 & 49.1 & 265.0 & 270.0 & 26.1 & 26.3 & 53.6 & 54.1 \\
\hline Mean & 30.1 & 30.3 & 37.7 & 37.6 & 234 & 241.2 & 20.1 & 20.4 & 40.9 & 40.0 \\
\hline
\end{tabular}

* Notes: ES - experimental set, SS - supervision set, SD - standard deviation, Min - minimal value, Max - maximum value, t1 - entry measurements, $\mathrm{t} 2$ - outcome measurements 
Table 6

Results of the $T_{2}$ test in experimental and supervision sets.

\begin{tabular}{|c|c|c|c|c|c|c|c|c|}
\hline \multirow[t]{2}{*}{ ES/KS } & $t_{1}$ & $t_{2}$ & $t_{1}$ & $t_{2}$ & $t_{1}$ & $t_{2}$ & $t_{1}$ & $t_{2}$ \\
\hline & \multicolumn{2}{|c|}{ Height $(\mathrm{cm})$} & \multicolumn{2}{|c|}{ Power (W) } & \multicolumn{2}{|c|}{ Velocity $(\mathrm{cm} / \mathrm{s})$} & \multicolumn{2}{|c|}{ Force $(\mathrm{N} / \mathrm{kg})$} \\
\hline SD & 3.0 & 2.0 & 5.8 & 3.5 & 55.0 & 34.0 & 2.1 & 2.8 \\
\hline Min & 28.9 & 39.0 & 28.3 & 40.8 & 137.0 & 129.0 & 17.1 & 19.9 \\
\hline Max & 37.3 & 44.8 & 44.3 & 50.9 & 306.0 & 218.0 & 23.8 & 27.7 \\
\hline Mean & 34.1 & 41.6 & 39.3 & 47.5 & 219.8 & 176.0 & 20.3 & 25.1 \\
\hline SD & 3.7 & 3.4 & 5.4 & 4.7 & 22.6 & 14.9 & 1.8 & 1.7 \\
\hline Min & 26.0 & 26.8 & 27.9 & 27.6 & 181.0 & 205.0 & 19.3 & 19.3 \\
\hline Max & 37.3 & 37.1 & 44.7 & 40.0 & 242.0 & 252.0 & 24.1 & 23.9 \\
\hline Mean & 33.0 & 33.2 & 37.2 & 35.9 & 217.4 & 228.6 & 20.6 & 20.7 \\
\hline
\end{tabular}

* Notes: ES - experimental set, SS - supervision set, SD - standard deviation, Min - minimal value, Max - maximum value, $x$

- average, $\mathrm{t} 1$ - entry measurements, $\mathrm{t} 2$ - outcome measurements

Table 7

Results of the $\mathrm{T}_{3}$ test in experimental and supervision sets.

\begin{tabular}{|c|c|c|c|c|c|c|c|c|}
\hline \multirow[t]{2}{*}{ ES/KS } & $t_{1}$ & $t_{2}$ & $t_{1}$ & $t_{2}$ & $t_{1}$ & $\mathrm{t}_{2}$ & $t_{1}$ & $t_{2}$ \\
\hline & \multicolumn{2}{|c|}{ Height $(\mathrm{cm})$} & \multicolumn{2}{|c|}{$\mathrm{T}$ of contact $(\mathrm{ms})$} & \multicolumn{2}{|c|}{ Reactivity } & \multicolumn{2}{|c|}{ Stiffness $(\mathrm{KN} / \mathrm{m})$} \\
\hline SD & 3.9 & 2.5 & 35.7 & 26.8 & 0.4 & 0.3 & 10.8 & 10.8 \\
\hline Min & 29.5 & 34.1 & 155.0 & 130.0 & 1.8 & 2.6 & 22.2 & 30.7 \\
\hline Max & 39.9 & 41.5 & 253.0 & 202.0 & 3.0 & 3.4 & 52.1 & 61.2 \\
\hline Mean & 33.6 & 38.7 & 207.2 & 168.8 & 2.5 & 3.1 & 36.2 & 43.3 \\
\hline SD & 2.3 & 2.2 & 127.2 & 99.6 & 0.8 & 0.8 & 9.3 & 9.8 \\
\hline Min & 30.8 & 30.9 & 121.0 & 159.0 & 1.1 & 1.1 & 30.6 & 28.1 \\
\hline Max & 37.2 & 37.1 & 492.0 & 445.0 & 3.6 & 3.3 & 56.2 & 57.2 \\
\hline Mean & 35.0 & 35.1 & 250.4 & 253.4 & 2.4 & 2.3 & 41.1 & 41.0 \\
\hline
\end{tabular}

* Notes: ES - experimental set, SS - supervision set, SD - standard deviation, Min - minimal value, Max - maximum value, $x$ - average, $\mathrm{t} 1$ - entry measurements, $\mathrm{t} 2$ - outcome measurements

Table 6 points out the changes measured in $T_{2}$ among both sets. The experimental set achieved significant improvement in this test as well. In the Power parameter (ES: increase by $7.5 \mathrm{~cm}$; SS: decrease by $0.3 \mathrm{~cm}$ ) Power (ES: increase by $8.2 \mathrm{~W}$, SS: decrease by $1.3 \mathrm{~W}$ ), Velocity (ES: increase by $43.8 \mathrm{~cm} / \mathrm{s}$, SS: decrease by $11.2 \mathrm{~cm} / \mathrm{s}$ ) and in the Force parameter (ES: increase by $4.8 \mathrm{~N} / \mathrm{kg}$, SS: $0.1 \mathrm{~N} / \mathrm{kg}$ ). The influence of the programme is evaluated to be positive for the improvement in all the parameters, based on the results of $\mathrm{T}_{2}$.

$\mathrm{T}_{3}$ pointed out changes in the Height, Time of contact, Reactivity and Stiffness parameters. It can be seen in Table 7, that significant improvement in all parameters was repeatedly found in the experimental set compared to the supervision set. Positive influence of the program can be, therefore, also considered based on $\mathrm{T}_{3}$.

\section{Table 8}

Results of the $\mathrm{T}_{4}$ test in experimental and supervision sets.

\begin{tabular}{cccc}
\hline ES/KS & $\mathrm{t}_{1}$ & $\mathrm{t}_{2}$ & $\%$ \\
\hline SD & 0.9 & 1.3 & 44.4 \\
Min & 8.9 & 9.3 & 4.5 \\
Max & 11.4 & 12.9 & 13.2 \\
Mean & 10.1 & 11.6 & 14.9 \\
SD & 0.8 & 0.9 & 12.5 \\
Min & 8.8 & 9.1 & 3.4 \\
Max & 11.2 & 11.5 & 3.6 \\
Mean & 9.7 & 10.1 & 4.1 \\
\hline
\end{tabular}

Table 8 shows the results of the $\mathrm{T}_{4}$ test - the max length of floating up after pushing off from the turning wall. The experimental set shows improvement on the level of average values by $14.9 \%$, while the supervision set shows these changes on level $4.1 \%$ (the difference based on the experimental factor was $10.8 \%$ ). 
Table 9

Results of the $T_{5}$ test in experimental and supervision sets.

\begin{tabular}{cccc}
\hline ES/KS & $\mathrm{t}_{1}$ & $\mathrm{t}_{2}$ & $\%$ \\
\hline SD & 1.4 & 1.8 & 28.6 \\
Min & 9.9 & 11.5 & 16.2 \\
Max & 13.6 & 16.4 & 20.6 \\
Mean & 11.9 & 14.6 & 22.7 \\
SD & 1.1 & 1.2 & 9.1 \\
Min & 9.9 & 10.6 & 7.1 \\
Max & 12.8 & 13.4 & 4.7 \\
Mean & 10.9 & 12.1 & 11.0 \\
\hline
\end{tabular}

In Table 9, the results of the test conducted in water, where the length of the push off after $25 \mathrm{~m}$ of breaststrokes in maximum speed with a push off from the wall of maximum floating up, while the distance was measured from the pool wall to the fingertips in floating position was observed. This test also shows more significant percentile increase in the experimental set, which improved the average values by $22.7 \%$ under the influence of the experimental factor, while the supervision set shows improvement by $11 \%$ (the difference based on the experimental factor was $11.7 \%$ ).

Kendall correlation coefficient (r) was used to figure out the statistical significance of the linear dependency between the conducted test in the experimental set, and it pointed out the average value of the correlation coefficient between the experimental factor and the individual tests as follows: $\mathrm{T}_{1}: \mathrm{r}=0.39, \mathrm{p}<0.05 ; \mathrm{T}_{2}: \mathrm{r}=0.41, \mathrm{p}<0.05 ; \mathrm{T}_{3}: \mathrm{r}$ $=0.43, \mathrm{p}<0.05, \mathrm{~T}_{4}: \mathrm{r}=0.38, \mathrm{p}<0.05$ a $\mathrm{T}_{5}: \mathrm{r}=0.41$, $\mathrm{p}<0.05$.

Plyometric exercises are utilized mostly for power and reactive force development due to the mechanism of accumulation and recuperation of elastic energy. During sportsmen preparation plyometric exercises seem to be very effective also confirmed by results of our findings. Positive impact to performance improvement in individual as well as in team sports confirmed several authors such as Cacek et al. (2018); de Villarreal, GonzálezBadillo \& Izquierdo (2008); de Villarreal et al. (2012); Chelly et al (2010); Asadi et al (2016); Saunders et al. (2006) or Paavolainen et al. (1999). In our research we found an increasement in explosive strength from $14.9 \%$ to $22.7 \%$, while
Sankey, Jones and Bampouras (2008) achieved improvement in explosive strength about $10.4 \%$ thanks to plyometric training protocol and Lubbers \& Potteiger (2003) achieved the same but with smaller difference for about $2.6 \%$.

\section{Conclusion}

The objective of the study was to analyse the impact of a specific training programme, which focuses on plyometric exercises for the selected movement abilities, and the selected parameters of swimming turns. The analysis of the results leads to the conclusion that the application of the experimental factor was effective, since the experimental set showed an increase between $14.9 \%$ and $22.7 \%$ in the indicators, while the supervision set, which trained without the programme showed decreased valued from $1.2 \%$ to increase values up to $11.0 \%$. The use of plyometric exercises is advised in training process of swimmers on dry land, based on the results. The implementation of a regular diagnosis of the observed movement ability, as well as a regular analysis of the techniques of a swimming turn with an objective to make it more effective during the swimming performance.

In conclusion, practice, improvement, and affectivity of the swimming turn can affect the swimmers' performance in races and improve it.

\section{Practical application}

The implementation of a regular diagnosis of the observed movement ability, as well as a regular analysis of the techniques of a swimming turn with an objective to make it more effective during the swimming performance. In conclusion, practice, improvement, and affectivity of the swimming turn can affect the swimmers' performance in races and improve it.

\section{References}

Asadi A, Arayi H, Young WB, DeVillarereal ES. The effects of plyometric training on change-ofdirection ability: A meta-analysis. International journal of sports physiology and performance, 2016; 11(5): 563-573. 
Baechle TR, Earle RW. Essentials of Strength Training and Conditioning. Champaign: Human Kinetics, 2008.

Brooks GA, Fahey TD, White TP. Excercise Physiology: Human Bioenergetic and its Applications.2 vyd. Mountain View, Caligornia: Mayfield Publishing Co. 1996.

Cacek J, Kalina T, Racek O, Hlavoňová Z, Králová T, Hammerová T, Ondráček J. Plyometrický trénink $\mathrm{v}$ př́pravě rychlostních a vytrvalostních sportovců.In Kondičnýtréning v roku, 2018.

Cacek J, Lajkeb P, Michalek J. Tréninksíly v atletice (metédaplometrická).Atletika.Praha $4:$ Českáatletikas.r.o. 2007. roč. 59, č.3, s. 17-20.

Cohen J. Statistical power analysis for the behavioral sciences (2nd edn). New York: Academic Press, 1988.

De Villarreal ES, Requena B, Cronin JB. The effects of plyometric training on sprint performance: A meta-analysis. J Strength Cond Res, 2012; 26(2): 575-584.

De Villarreal ESS, Gonzaless-Badillo JJ, Izquiredo M. Low and moderate plyometric training frequency produces greater jumping and sprinting gains compared with high frequency. J Strength Cond Res, 2008; 22(3): 715-725.

Chelly MS, Ghenem MA, Abid K, Hermass S, Tabka Z, Shepard R J. Effects of in-season short-term plyometric training program on leg power, jumpand sprint performance of soccer players. J Strength Cond Res, 2010; 24(10): 2670-2676.

Chu D. Jumping into plyometrics. Leeds: Human Kinetics, 1998.

Chu DA, Myer G. Plyometrics. Champaign: Human Kinetics, 2013.

Jančoková L. Biorytmy $\mathrm{v}$ športe (S úvodom do chronobiológie). BanskáBystrica: FHV UMB, 2000 .

Kurz T. Science of sports training: how to plan and control training for peak performance (2nd ed). Island Pond, Vt: Stadion, 2001.

Kutz M. Theoretical and practical issues for plyometric training.In NSCA's Performance Training Jurnal. 2008; 2(2): 10-12.

Luebbers P, Poteiger J. 2003. Effects of Plyometric Training and Recovery on Vertical Jump
Performance and Anaerobic Power. J Strength Cond Res, 2003; 17(4): 704-709.

McGlashan L. Plyometria pre výbušnost'. In Muscle\&Fitness, 2004, roč.8, č.7.

Paavlainen L, Hakkinen K, Hamalainen I, Nummela A, Rusko H. Explosive-strength training improves 5$\mathrm{km}$ running time by improving running economy and muscle power. Journal of Applied Physiology, 1999; 86(5): 1527-1533

Psotta R. Fotbal: kondiční trénink: moderní koncepce tréninku, princípy, metody a diagnostika, troriesportovního tréninku. 1.vyd. Praha: Grada, 2006.

Pupišová Z. Rozvoj výbušnej sily dolných končatína jej v plyvna efektívnost' štartové ho skoku v plávaní.Krakov: Spolok Slovákov v Pol’sku. 2013.

Radcliffe JC, Farentinos RC. Higkt-powered plyometrics. In Human Kinetics. United States od America, 1999.

Sankey S, Jones P, Bampouras M. Effects od two plyometric training programmes of different intensity on vertical jump performance. Serbian Jurnal of Sports Sciences, 2008; 2(1-4): $123-130$.

Saunders PU, Telford RD, Pyne DB, Peltola EM, Cunningham RB, Gore CJ, Hawley JA. Short-term plyometric training improves running economy in highly trained middle and long distance runners. J Strength Cond Res, 2006; 20(4): 947.

Slamka M. Akumulačno-rekuperačný cyklus svalovej práce a jehovy užitie $\mathrm{v}$ športe.In: Zborník vedeckých prác katedry atletiky IV, Bratislava: Slovenská vedecká spoločnost̉ pre TV a šport, 2000: 13-25.

Tihanyi J. Development of Explosive Strenght According to Musile Fibers Types. Modern Atlete and Coach, 2002: 12-15.

Vanderka M, Kampmiller T. Pružino výpohybový systém ludského organizmu. In Atletika 2008. Zborník z medzinárodnej vedeckej konferencie, Univerzita Konštantína Filozofa v Nitre, Pedagogická fakulta, Katedra telesnej výchovy a športu, 2008: 230.

Zatsiorsky VM, Kraemer WJ. Science and Practice of Strength Training. Champaign: Human Kinetics, 2006. 